\title{
Becoming a Qualitative ESL Researcher: A personal monologue
}

\author{
Irfan Ahmed Rind \\ Sukkur IBA University \\ Correspondence concerning this article should be addressed to Irfan Ahmed Rind, Airport Road, Delhi \\ Muslim Housing Society, Sukkur, Sindh, Pakistan.E-mail: irfan.rind@iba-suk.edu.pk
}

\begin{abstract}
This reflective paper narrates my research journey from a naïve researcher to a critic and from a behaviorist to a post-structuralist. It highlights the different philosophical, methodological, and theoretical dilemmas I faced in conceptualizing students' experiences in an English as a Second Language program in higher education during my doctoral studies. This journey is divided into three phases: construction, deconstruction, and reconstruction. In the construction phase, I conceptualized students' experiences from my own established knowledge, which was grounded in my presumptions about teaching and learning. During the deconstruction phase, I questioned my understanding of knowledge and social realities. In the reconstruction phase, I interacted with Phenomenography, Activity Theory, Symbolic Interactionism, Communities of Practice, and Bourdieusian Structuralism. This paper narrates these interactions, focusing mainly on the dilemmas I faced as a researcher. These reflections could be highly beneficial for new researchers who may face the same situations at different stages of their research careers.
\end{abstract}

Keywords: reflexivity, self-conversation, qualitative research, philosophical stance, social stance, novice researchers

\section{Introduction}

This paper presents a reflective journey to becoming a researcher while examining students' learning experiences in an English as a Second Language (ESL) program in a higher education institute as a topic for my Ph.D. (see the summary of the original research in Rind, 2014; and the full research study in Ahmed, 2012). The $\mathrm{Ph}$.D. research was based on the assumption that learning a second language is a complex process in which several individuals and social factors play vital roles in shaping students' ESL learning experiences. In the process of examining these individual and social factors, I reflected on the way I developed a theoretical understanding of students' ESL learning, as well as of myself as a researcher. This paper narrates these reflections during different developmental stages of becoming a researcher. The purpose of these reflections can be effectively summarized in the words of Glesne (2016):

Learning to reflect on your behavior and thoughts, as well as on the phenomenon under study, creates a means for continuously becoming a better researcher. Becoming a better researcher captures the dynamic nature of the process. Conducting research, like teaching and other complex acts, can be improved; it cannot be mastered (p. xiii).

I have been inspired by researchers such as Cohen and Crabtree (2006), Finlay (2002), Glesne (2016), Malterud (2001), and many others who highlighted the importance of reflection for new researchers. As a new researcher, I experienced strong anxiety at the outset of my Ph.D. research. Although the literature on qualitative research was a source of some comfort, I found that I was the primary instrument of data collection and analysis. This process led me to realize that reflexivity is essential for conducting a compelling research study on my topic. Cohen and Crabtree (2006) defined reflexivity as an attitude for systematically attending to the context of knowledge construction, especially to the effect of the researcher, at every step of the research process. Malterud (2001) argued that "a researcher's background and position will affect what they choose to investigate, the angle of investigation, the methods judged most adequate for this purpose, the findings considered most appropriate, and the framing and communication of conclusions" (p.483-484). The perspective or position of the researcher shapes all research whether qualitative, quantitative, or mix-method. Although I found this 
argument very convincing on a theoretical level at the beginning of the research process, I had little idea what this meant in concrete terms.

However, this began to change in the first year of my doctoral studies, when my supervisor asked me to revise my initial research proposal and reconsider my research questions. During this time, I began to reflect on my research by recording self-conversations. These personal narratives helped me identify why I had chosen the topic of the study, how my assumptions about teaching and learning had informed my initial research proposal, and how these assumptions guided my methodology.

This first stage of reflection allowed me to realize that I had undertaken my doctoral studies with numerous assumptions about teaching and learning. Like many novice researchers, I assumed that I was familiar with all the problems faced by ESL students in the university where I wanted to conduct my research. This was mainly due to my positionality as an insider, as I had both studied for four years and taught ESL for a year and a half at that university. Before starting my doctoral studies, I had assumed that students faced problems in the ESL program due to certain behaviors; my interest, therefore, lay in introducing an intervention that would change these behaviors and improve their learning outcomes.

After reflecting on these assumptions, I realized that I was viewing students' learning experiences from a behaviorist perspective. That is, the learning process is a way to construct or modify behaviors. These initial reflections also served as a memory prompt that encouraged the second stage of reflection after I had carried out my research. Reflecting on further self-conversations, I made connections between the methodology literature, decisions taken during the research, the process of reflexivity, and my evolving understanding of the complexities inherent in qualitative research. By analyzing these self-conversations, I became more aware of how I had managed each research stage, the issues and tensions that had arisen, and how I had dealt with these issues as a researcher.

A retrospective examination of my research, therefore, permitted me to make meaningful connections between theory and practice. Moreover, this process of reflection provoked in-depth learning, which may not have been achieved through other methodological means. The experience of reconsidering my initial research proposal for my doctoral studies led me to realize that reflection is an essential mediator of the research process. Most importantly, the reflective self-conversations allowed me to meaningfully construct a personal sense of what it means to become a researcher. This paper attempts to narrate these self-conversations and ways in which I, as a researcher, developed in phases, i.e., construction, deconstruction, and reconstruction.

\section{Construction Phase (Occupied with Assumptions)}

Unsurprisingly, the process of research did not seem to be as deep and complicated as I initially assumed. This was mainly because of my established assumptions related to the topic of my choice, i.e., analyzing students' learning experiences in an ESL program in higher education. My positionality as an insider concerning this research (Bryman, 2016), where I lived in the context, experienced the ESL program as a student, and taught the language as an instructor, made me believe that I knew everything about the ESL program. I firmly believed that I could write a convincing Ph.D. thesis without even collecting data from my research participants. Indeed, the very choice of the topic for my doctoral study was based on my experiences, which shaped my assumptions about the weaknesses and strengths of programs of this kind as well as the challenges and opportunities it offered to the students and teachers. Therefore, I firmly felt that I was the best person to conduct this research as I knew almost everything in this domain.

In my initial proposal, I assumed that students faced problems in the ESL program because of certain 'bad behaviors', i.e., not paying attention to lectures, not revising the lessons at home, choosing to sit in the backbenches of the large classroom to avoid participation, and so on. Assuming that I already knew the problems, my focus should have been to introduce some interventions to change these behaviors for a better outcome.

[...] I know what is their [university students'] problem [in ESL] and I know how to fix it. I faced it [the problems] myself [as a student]. Remember the time when I struggled in concentrating on the lectures. Z [anonymized friend's name] struggled because he liked to sit at the 
backbenches. X and Y [anonymized friends' names] hardly studied at home. See, these are their problems, and my students must be doing the same. [...] So, let's write the proposal accordingly. Let's propose a new method or something that makes these students change these habits. Think in this direction.

(Reflective note, $12^{\text {th }}$ December, 2008)

However, to reinforce what I already knew, I developed a set of closed-ended questions and conducted a survey. The items in the questionnaire were developed based on my understanding of the challenges and opportunities of the ESL program. Students were required to respond with yes or no to some items and select the relevant percentage category in response to others. The questionnaire contained items like 'Do you face difficulties in listening skills?', 'How much (in percentage) do you understand the lectures in English?', 'How much (in percentage) do you participate in the class?', and so on. In brief, the items were quite straightforward and did produce the expected results. However, they were far from conducting an in-depth investigation into students' ESL learning experiences. Indeed, the survey was just a way to reassure me of the validity of my assumptions. Even more, I had planned an intervention to remedy these assumed problems and bring changes in students' behaviors before the survey results were even generated.

The results [from the questionnaire] look promising. [...] almost all my assumptions turned out to be true. So, the next task is to (1) present it to X [anonymized Ph.D. supervisor's name], (2) develop an intervention. $\mathrm{X}$ is back in his office by 14 Jan, so I should work on developing an intervention. Let's say, on the $14^{\text {th }}$, I am going to present both findings [of the questionnaires] and intervention to $\mathrm{X}$, and also develop a timeline to implement the intervention.

(Reflective note, $5^{\text {th }}$ January, 2009)

Soon, I realized the simplicity of my methodology through the shallowness of my findings. Of course, my supervisor played a vital role in making me rethink my overall research approach. He advised me to stop thinking about the students' learning experiences and instead reflect upon my understanding of knowledge and social reality. He posed questions like 'what is knowledge for you?', 'how can you acquire this knowledge?', 'how do you see society and social actors?', and 'how do you see the social interaction of social actors?'

Okay, this was unexpected. [...] But let's sort it out one by one. Let's park the questionnaire findings aside, as well as the intervention plan. Let's first listen to X's conversations again [my supervisor allowed me to tape-record our conversations]. So, first, listen and transcribe X's conversation for better understanding. Then highlight all the issues he raised and let's plan to address these issues one by one.

(Reflective note, $14^{\text {th }}$ January, 2009)

\section{Deconstruction Phase (Self-Exploration)}

I, like many others, became a researcher from a "background where the practice is seen as unproblematic and expectations of research are directed towards positivist assumptions about generating evidence" (Dunne, Pryor, \& Yates, 2005, p.4). However, based on the constant feedback from my supervisor, peers, and my readings, I realized that my research would be judged against criteria involving the questioning of common-sense notions of research practice, knowledge, and social reality. I, therefore, had to first explore the logic of my research practices and explore my understanding of knowledge and social reality, and the tensions inherent in these. This raised some important questions (i.e., how I see social settings and social actors) that I had to reflect upon before I researched students' ESL learning experiences.

\section{How do I See Social Settings and Social Actors?}

Initially, I conceptualized students' ESL learning experiences in isolation. In other words, I thought that students' ESL learning experiences were shaped by their own choices and actions, which were independent of the context in which these experiences took place. Soon I realized, as Scott $(1999$, p.2) suggested, that a researcher must work between "structures/mechanisms of society and the practical consciousness of social actors". A researcher must realize that research in social settings is often recursive in nature (Dunne et al., 2005), which means that if I wanted to understand students' ESL learning experiences, I needed to take into consideration contexts wider than the immediate social action in which I was a research-designer and the 
students, as research-objects, were participating. In other words, I needed to take a stance and decide if I considered social actors (students) as independent in making their choices and actions, and solely responsible for the consequences with little influence from the social setting. Or if it was the classroom norms, institutional policies and practices, and/or the wider field of higher education in which this institute operates (social setting) was responsible for students' actions and choices.

[...] this is interesting, so students' choices are not independent of the context, or are they? Okay, let's think about it. Let's say I am a student, and when I make a choice, it is made without keeping the context in mind, or otherwise? Okay, I make my choices based on my wishes and interests, but I also cannot make any choice that is not acceptable in my social context. So, what does this show? Does this show that my all choices are influenced by the social structure? [...] this is slightly confusing, so let's read a little more on it before deciding.

(Reflective note, $3^{\text {rd }}$ March, 2009)

To make this decision, I needed to understand the "complexity of social settings and the ensuing difficulty this creates for separating the effects of different variables" (Scott, 1999, p.2). My readings into this matter raised an interesting question: is the complexity of any social setting inherent in it, or do I, as a researcher, read the complexity into social action? For example, if I see a student not participating in an ESL classroom, then the potential for an analytic description is almost infinite (Dunne et al., 2005). There are several disciplinary lenses that I can use to describe this phenomenon from micro to macro levels. For example, I may choose a neurological perspective, cognitive perspective, or one of the many sociological perspectives. This means that if I choose a cognitive perspective, my construction of the students and their experiences would be radically different from that of a social perspective. This is mainly because each perspective uses a different lens to see the same individual and phenomenon and draws different conclusions(Dunne et al., 2005).

So which perspective should I choose to get a valid conclusion? Dunne et al. (2005, p.13) suggest that

\begin{abstract}
Researchers sometimes work with unexamined and vernacular models of the person. In order to make sense of social action, researchers often make the assumption, and it is worth examining, that people act reasonably within a cause-effect model of social action. For psychologists and phenomenologists the answer might be at the level of the individual, while for structuralists of all sorts, from functionalists to Marxists, the individual is largely determined by the wider realities of social forces. For some postmodernists and Foucauldians, the subject may be understood as an effect rather than a cause and the subjective experience of self, seen as a powerful effect of those wider discourses that shape our being.
\end{abstract}

Does this mean that all the perspectives are authentic, and all the conclusions help in understanding the same phenomenon from different dimensions? Up to that point in time, I had not experienced that yet. I needed to take a social stance to 'find out' students' learning experiences in the ESL program. Before I explored my social stance, I needed to reflect on what knowledge is and how I, as a researcher, could acquire this knowledge.

\title{
What is Knowledge and How Can I Acquire It?
}

To understand students' ESL learning experiences, it was crucial to first question my own assumptions about the nature of knowledge and the world, and how I, as a researcher, express or interpret the reality. This process of interrogation began with questions such as 'what is knowledge?', and 'how is it acquired?'. Seeking answers to these questions led me to epistemology. Heylighen (1997) asserts that epistemology essentially attempts to answer basic questions such as, "what distinguishes true (adequate) knowledge from false (inadequate) knowledge?" (p.1).

$\mathrm{X}$ [anonymized supervisor] said (1) “you are examining students' experience, which means you are trying to know something new or constructing new knowledge. So, what do you, as a researcher, mean by knowledge? How do you conceptualize knowledge? What is knowledge for you? [...] (2) how do you acquire knowledge? [...]" He [supervisor] pointed out that the answer to all questions should align. The most important point to today's meeting [with supervisor] is to clearly explain myepistemological and ontological stance and link it with my methodology and social stance.

(Reflective note, $17^{\text {th }}$ February, 2009) 
In the context of social research, such questions translate into issues of scientific methodology: how can one develop theories or models that are better than competing theories? My primary focus was not to develop a theory or model but to select a theory or model that supports a holistic account of students' learning experiences from their perspectives and within their contexts. This approach can be seen in the following discussion where I shifted from a psychological perspective to the sociological constructs of identity, community, and institutional influences. The departure from a psychological perspective was influenced by the approach's detachment of the individual from his or her context (Ashwin, 2012); from my perspective, knowledge of students' learning experiences is inadequate when it is not understood within its specific context. This approach defined my epistemological position as interpretivist, due to my underpinning assumption that "all human actions are meaningful and have to be interpreted and understood within the context of social practices. To make sense of the social world, the researcher needs to understand the meanings that form and are formed by interactive social behavior" (Scott \& Usher, 1996, p.18). However, I later acknowledged the fact that interactive social behaviors are also formed within social structures (as discussed in detail in the following discussion).

As an interpretivist, I believed that in order to understand an individual's behavior, attempts should be made to view the world from that individual's viewpoint. However, any individual's viewpoint is inevitably shaped by their particular context. The researcher must obtain access to the individuals' contexts in order to interpret their reality from their point of view. And within an interpretive framework, the researcher attempts to make sense of what he or she is researching. Bryman (2016) labels this process double hermeneuticthrough the process of social research, both the subject (the researcher) and the object (other participants in the study) of the research share the position of an interpreter or sense seeker. This means that a researcher must understand how participants view their reality, but also make sense of what he or she makes out of the participants' reality and how he or she defines their findings in the light of existing literature. As Bryman (2016, p.14) asserts,

\begin{abstract}
When social scientists adopt an interpretivist stance, they are not simply laying bare how members of a social group interpret the world around them. The social scientists will almost certainly be aiming to place the interpretations that have been elicited into a social scientific frame. There is a double interpretation going on: the researchers are providing an interpretation of others' interpretation. Indeed, there is a third level of interpretations going on, because the researchers' interpretations have to be further interpreted in terms of the concepts, theories, and literature of the discipline.
\end{abstract}

I also realized that the questions of social ontology cannot be detached from issues related to conducting social research. Bryman (2016) argues that ontological assumptions and commitments feed into the formulation of research questions and the way in which research is carried out. Following an interpretivist approach, constructivism forms the basis of the ontological position from which I approached reality, as well as the ontological assumptions that had guided the formulation of my research questions. Unlike objectivism, which argues that social phenomena and their meanings have an existence that is independent of social actors, constructivism asserts that social phenomena and their meanings are continually accomplished by social actors. It implies that social phenomena and categories are not only produced through social interaction, but are also in a constant state of revision, and therefore produce multiple and amendable realities (Bo et al., 2020; Fry et al., 2008; Rind \& Ning, 2020). This approach was, therefore, particularly appropriate for my research, which sought to understand the hows and whys of students' ESL learning experiences.

\title{
Reconstruction Phase (Informed Conceptualization)
}

Soon, I realized that the constructivist ontological and interpretivist epistemological stances traverse the fields of phenomenology, hermeneutics, ethnography, and phenomenography. The phenomenologists believe that in order to understand an individual's behavior, one should attempt to view the world from that individual's viewpoint. The job of the researcher is to gain access to the respondents' unique contexts in order to interpret their reality from their point of view (Bryman, 2016). Hermeneutics holds that research is about understanding human behavior rather than explaining it. Ethnographic studies are holistic, originating from the idea that humans are best understood in the fullest possible context (Richardson, 2000). The assumption that underlines phenomenography is that one can understand students' learning and their learning situations from students' 
points of view (Marton \& Säljö, 1976). Marton and Säljö (1976) also succinctly describe phenomenography as "a change in someone's capability for experiencing something in certain ways" (p. 208).

I chose the phenomenographic approach as it rejects a positivistic view of learning and portrays earlier quantitative research as too "detached" (Entwistle, 1997, p.13). In fact, the phenomenographic perspective emerged as a reaction to traditional, behaviouristic approaches to learning second languages such as B. F. Skinner's Stimulus-Response Theory and Robert Lado's Contrastive Analysis Hypothesis (Ashwin, 2012). From a behaviouristic perspective, language is perceived as a system of habits and second language learning proceeds by producing a response to a stimulus and receiving either positive or negative reinforcement. This is what I believed before I questioned the logic of my research inquiry. I realized that I was a behaviorist and tried to approach students' ESL experiences from a behaviouristic perspective. I assumed that students developed bad habits that hindered their second language learning. I, therefore, needed to develop an intervention that would work as reinforcement to generate desired behaviors. However, locating myself in constructivism and interpretivism, I found phenomenography to be a suitable theoretical framework for exploring students' learning in ESL.

I quickly realized that the phenomenographic perspective has been importantly critiqued for its individualistic approach to understanding students' learning in ESL (see details in Ahmed, 2012); nevertheless, unlike previous behaviouristic and neurological approaches to understanding ESL teaching and learning, the phenomenographic research tradition has tried to consider issues relating to the context. These contextual issues are only covered to a very limited extent in phenomenographic research, but this research tradition can be credited with moving from a notion of fixity to the notion of variability in ESL learning. I, therefore, aimed to locate myself within this theory of variability in learning, but at the same time sought to use this notion of variability within a more context-specific understanding of ESL teaching and learning. In particular, I was interested in understanding how certain variables impact ESL teaching and learning from the students' perspective. Thus, I needed to find a theory that could explain different variables affecting teaching and learning in the context of ESL.

To this end, I found Engeström's (2001) Activity Theory to be a suitable analytical tool for conceptualizing students' ESL learning experiences from their perspective and within their contexts. Activity Theory was developed from the work of Vygotsky (1980), whose triangular model of "a complex, mediated act" (p.40) was fundamental for illustrating the relationship between the human agent and objects in their environment, as mediated by cultural means, tools, and signs. As the model in Figure 1 depicts, the mediation process is twoway (represented by two-sided arrows); individuals actively shape the forces that are active in shaping them, and this process "lies at the heart of the many attempts to develop our understanding of the possibilities for interventions in processes of human learning and development” (Daniels, 2004, p.121).

\section{Figure 1}

Vygotsky's triangular model of a complex, mediated act

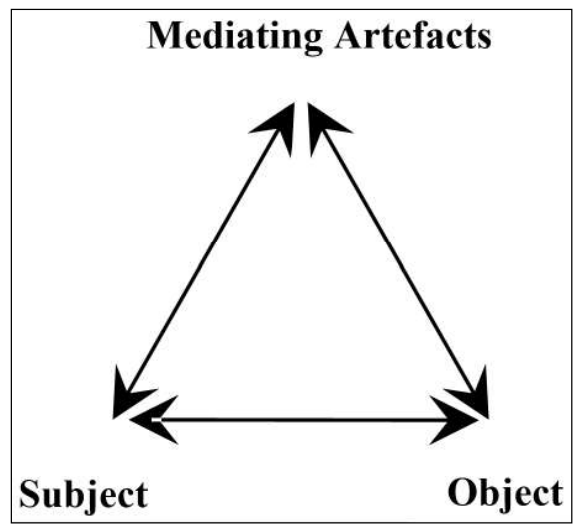

Leont'eV (1982) developed the second generation of Vygotsky's model, which distinguished between individual action and collective activity. Leont'eV viewed the activity system as incorporating three hierarchical processes driven by a different individual or communal motive. These ideas were further developed by Engestrom (1987) as illustrated in Figure 2. 
Within the Activity Theory approach, learning and other human activities are understood as being integrated into a larger system, or an activity. An activity is a theoretical entity, discerned, described, and used by the researchers to consider the socially-based nature of the human activity. The interacting constituents of the activity continuously develop into new forms that together create an activity. Used in this way, Activity Theory serves as a clarifying and descriptive tool rather than a strongly predictive theory (Nardi, 1996) and does not prescribe any particular way of understanding learning or a fixed ontology(Berglund, 2004; Havnes, 2004). Several researchers found this theoretical approach useful for understanding ESL teaching and learning (Hawkins, 2008; Lantolf, 2014; McCafferty, 2002; Roebuck, 2000). I also found it useful and, therefore, adopted it to generate a model for a student learning activity in the ESL program by identifying different variables (see Figure 3). This model highlighted important factors such as students' identities, the community within the ESL classroom, and institutional influences on different variables that shape students' learning experiences.

\section{Figure 2}

Engeström's model of an activity system

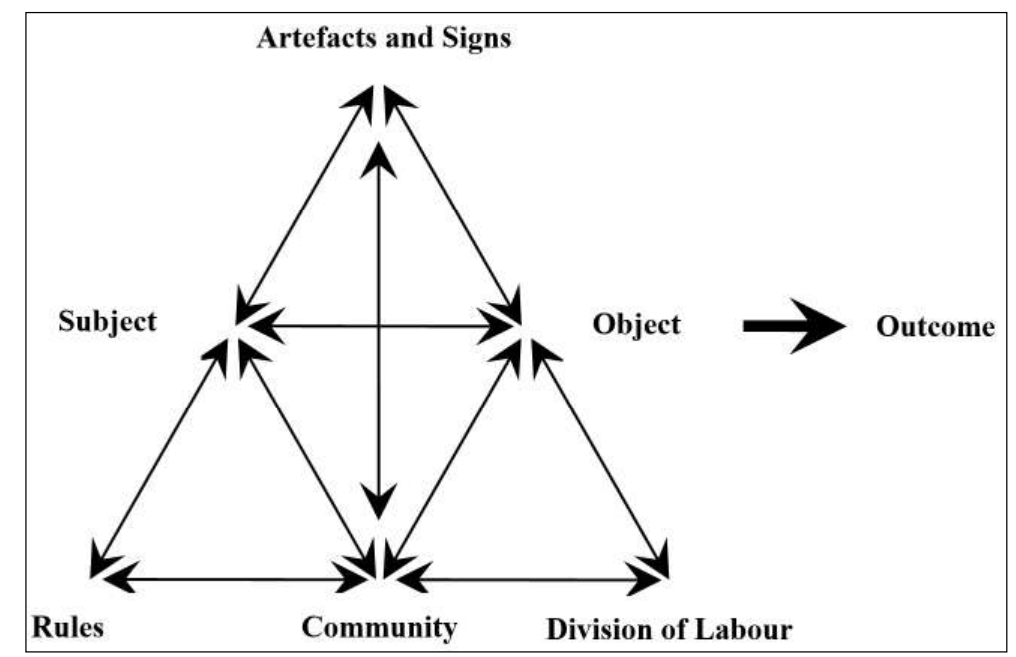

Note. Adapted from “Learning by expanding: An activity-theoretical approach to developmental research,” by Y. Engestrom, 1987, p. 78. Copyright 1987 by the Orienta-Konsultit.

\section{Figure 3}

My conceptual understanding of students' learning experiences using Activity Theory

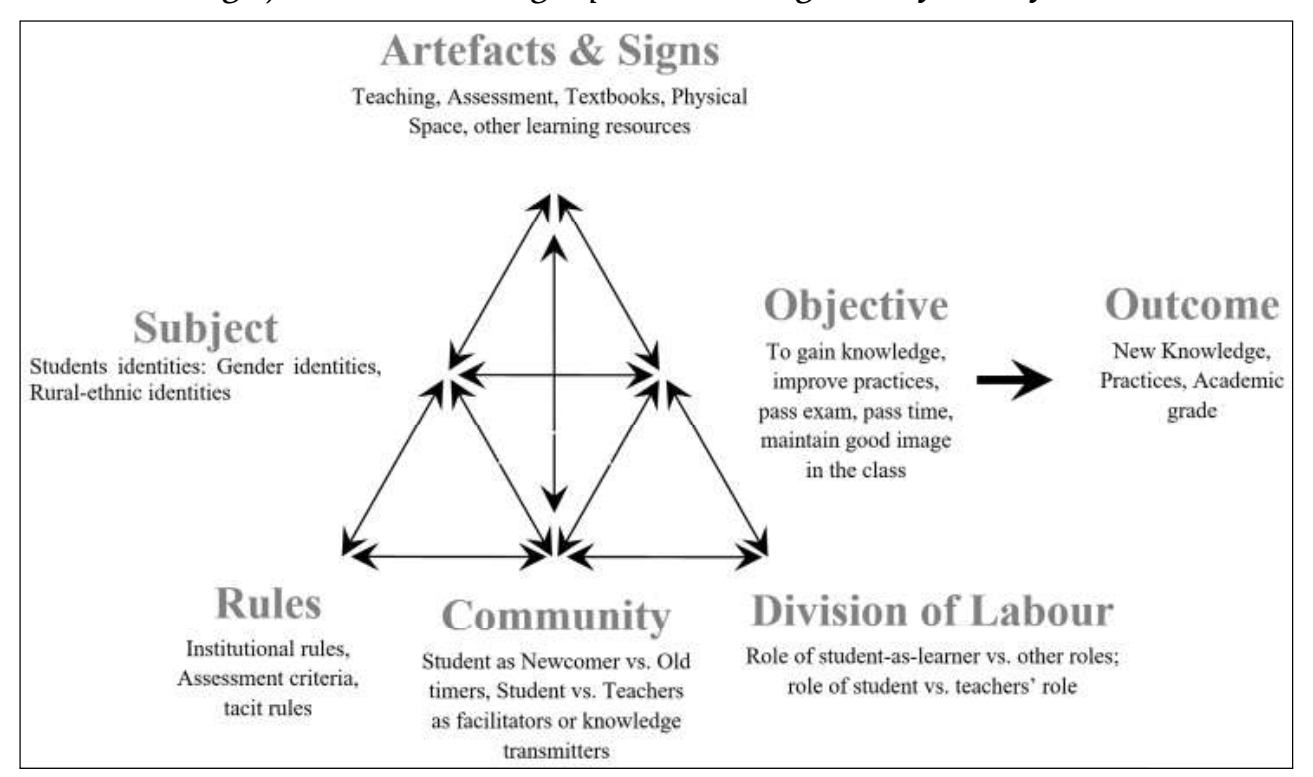

Note. Adapted from "Investigating students' experiences of learning English as a second language at the University of Sindh, Jamshoro, Pakistan" by I. Ahmed, 2012, The Sindh University Journal of Education-SUJE, 45(1), 1-20. Copyright 2012 by I. Ahmed. 
However, Activity Theory does not offer conceptual insights into the notions of institutional influence, community, and identity. I, therefore, decided to use Activity Theory to a limited extent, i.e., to explain variables in students' learning experiences (Rind, 2016a). I did not adopt it as an overarching theoretical framework for my research. Nevertheless, my brief interactions with Activity Theory were useful for enabling me to finally focus on the use of institutional influence, community, and identity for further analysis. I wanted to employ the concept of institutional influence to examine the impact of the university's policies and practices on the teaching and learning in the ESL program (for details see Rind \& Kadiwal, 2016). I saw students and teachers in the ESL classroom as a community, therefore I wanted to use the concept of community to examine the studentstudent and student-teacher interactions (for details see Rind, 2016b). I also wanted to use the notion of identity to examine the interactions among students' gender identities (for details see Rind, 2015), rural-ethnic identities (for details see Rind et al., 2016), and disciplinary identities (for details see Rind \& Alhawsawi, 2013) within different aspects of the ESL program (see Figure 4).

\section{Figure 4}

My conceptual understanding of students' learning experiences using the sociological lenses of identity, community, and institutional influences

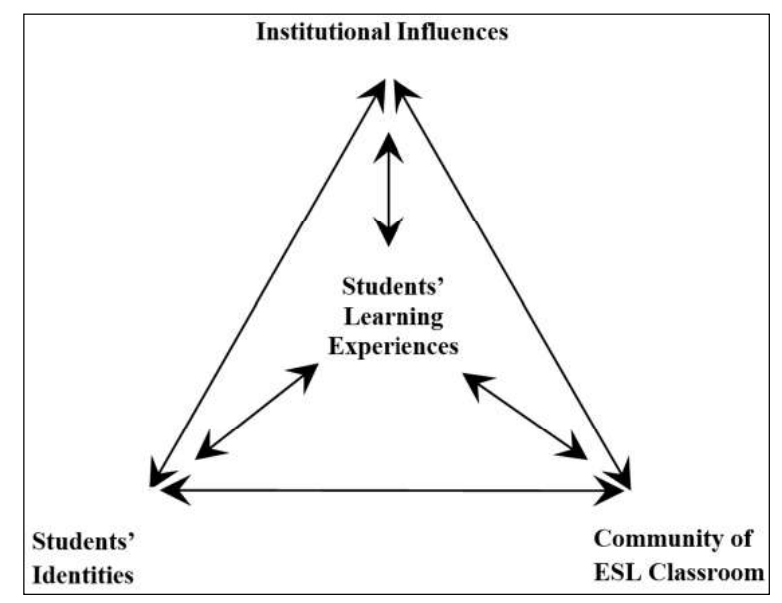

Note. Adapted from "Investigating students' experiences of learning English as a second language at the University of Sindh, Jamshoro, Pakistan" by I. Ahmed, 2012, The Sindh University Journal of Education-SUJE, 45(1). Copyright 2012 by I. Ahmed.

This conceptual framework offered a three-dimensional view (i.e., at a micro level, the interactions of students' different identities within the ESL program; at the meso level, the interactions of students with teachers and peers; and the macro level, the interactions of students' experiences with the policies and practice of the institute) into students' ESL learning experiences. These experiences are presented in detail in different published works. The interactions of students' different identities are presented in Rind and Alhawsawi (2013), Rind (2015), and Rind et al. (2016). Likewise, the detailed findings on the interactions of students with peers and teachers are presented in Rind (2016b). Finally, the details of how institutional influences shape students' experiences in ESL are presented in Rind and Kadiwal (2016).

\section{Conclusion}

In this paper, I attempted to reflect upon the different processes that shaped my positionality, perspective, beliefs, and values in relation to the research that I conducted to evaluate students' learning experiences with ESL in higher education. It is important because, as a qualitative researcher, I have often constructed the reality of the participants as the human research instrument. Therefore, reflexivity becomes a defining feature for me as a qualitative researcher. Considering that a qualitative researcher should attempt to be aware of their roles in the (co)-construction of knowledge, I tried to make it clear in my narratives how intersubjective elements impacted my data collection and analysis to enhance the trustworthiness, transparency and accountability of my research. However, the process of engaging in reflexivity is full of muddy ambiguity and multiple trials as researchers are needed to negotiate the swamp of interminable deconstructions, self-analysis, and self-disclosure. This ambiguity is more confusing for novice qualitative researchers who struggle with issues of subjectivity in their research. 
Dealing with these issues as a novice qualitative researcher, I reflected upon how I have developed as a researcher in different stages while navigating my way to a piece of research that is both in-depth and trustworthy. Earlier research focusing on the dilemma of qualitative researchers promoted subjectivity as an opportunity rather than a problem if researchers effectively use reflexivity. However, no universal guidelines are given for the effective use of reflexivity. This paper contributes by presenting examples of how self-conversations and reflective notes became a great opportunity for me as a novice qualitative researcher to keep a check on my subjectivity. At the same time, they also demonstrated how I used these self-conversation and reflective notes to show my presence in my research to produce reflective yet authentic research. Presenting more and more reflective narratives to novice researchers may help them understand this process. This paper attempts to do the same, by presenting my reflections on my research processes and the ways I dealt with my subjectivity when developing a theoretical framework to understand students' learning experiences. Following some of these steps, many novice researchers may balance their subjectivity in their research, ensure the trustworthiness of their methodology, and achieve indepth context specific analysis of their topics.

\section{Acknowledgments}

I would like to thank Prof. Sayed Yusuf, my Ph.D. supervisor, who guided me along this entire research journey. I would also acknowledge the contribution of Dr. Sajjadllah Alhawsawi for being an exceptional critical friend on this journey.

\section{Reference}

Ahmed, I. (2012). Investigating students' experiences of learning English as a second language at the University of Sindh, Jamshoro, Pakistan. The Sindh University Journal of Education-SUJE, 45(1), 1-20. http://sujo.usindh. edu.pk/index.php/SUJE/article/view/2320

Ashwin, P. (2012). Analysing teaching-learning interactions in higher education: Accounting for structure and agency. A\&C Black.

Berglund, A. (2004). A framework to study learning in a complex learning environment. Association for Learning Technology Journal, 12(1), 65-79. https://doi.org/10.3402/rlt.v12i1.21457

Bo, N., Rind, I. A., \& Asad, M. (2020). Influence of teacher educators on the development of prospective teachers' personal epistemology and tolerance. Sage Open, 10(1), 1-14. https://doi.org/https://doi. org/10.1177/2158244020914639

Bryman, A. (2016). Social research methods. Oxford University Press.

Cohen, D., \& Crabtree, B. (2006). Qualitative research guidelines project. http://www.qualres.org/index.html

Daniels, H. (2004). Activity theory, discourse and Bernstein. Educational Review, 56(2), 121-132. https://doi. org/10.1080/0031910410001693218

Dunne, M., Pryor, J., \& Yates, P. (2005). Becoming a researcher: A research companion for the social sciences: A companion to the research process. McGraw-Hill Education.

Engestrom, Y. (1987). Learning by expanding: An activity-theoretical approach to developmental research. OrientaKonsultit.

Engeström, Y. (2001). Expansive learning at work: Toward an activity theoretical reconceptualization. Journal of Education and Work, 14(1), 133-156. https://www.tandfonline.com/doi/abs/10.1080/13639080020028747

Entwistle, N. (1997). Contrasting perspectives on learning. The Experience of Learning, 2, 3-22.

Finlay, L. (2002). Negotiating the swamp: the opportunity and challenge of reflexivity in research practice. Qualitative Research, 2(2), 209-230. https://doi.org/10.1177/146879410200200205

Fry, H., Ketteridge, S., \& Marshall, S. (2008). A handbook for teaching and learning in higher education: Enhancing academic practice. Routledge.

Glesne, C. (2016). Becoming qualitative researchers: An introduction. ERIC.

Havnes, A. (2004). Examination and learning: an activity-theoretical analysis of the relationship between assessment and educational practice. Assessment \& Evaluation in Higher Education, 29(2), 159-176. https:// doi.org/10.1080/0260293042000188456

Hawkins, B. (2008). Using sociocultural theory to examine the context (s) of language learning and teaching. Studies in Applied Linguistics and TESOL, 8(1). https://doi.org/10.7916/salt.v8i1.1498

Heylighen, F. (1993). Epistemology: Introduction. http://pespmc1.vub.ac.be/EPISTEMI.html 
Hopman, J. (2021). Fieldwork supervision: Supporting ethical reflexivity to enhance research analysis. International Journal of Research \& Method in Education, 44(1), 41-52. https://doi.org/10.1080/174372 7X.2019.1706467

Lantolf, J. (2014). (S) econd (L) anguage (A) ctivity theory: Understanding second language learners as people. In Learner contributions to language learning: New directions in research (pp. 141-158). Taylor and Francis.

Leont'eV, A. N. (1982). Problems of the development of the mind. In Progress Publishers. Progress.

Malterud, K. (2001). Qualitative research: standards, challenges, and guidelines. The Lancet, 358(9280), 483-488. 10.1016/S0140-6736(01)05627-6

Marton, F., \& Säljö, R. (1976). On qualitative differences in learning: I-Outcome and process. British Journal of Educational Psychology, 46(1), 4-11.

McCafferty, S. G. (2002). Gesture and creating zones of proximal development for second language learning. The Modern Language Journal, 86(2), 192-203. https://doi.org/10.1111/1540-4781.00144

Nardi, B. A. (1996). Context and consciousness: activity theory and human-computer interaction. MIT press.

Richardson, L. (2000). Evaluating ethnography. Qualitative Inquiry, 6(2), 253-255. https://doi. org/10.1177/107780040000600207

Rind, I. A. (2014). Investigating students' experiences in an ESL programme at the University of Sindh, Jamshoro, Pakistan. Compare, 44(6), 1002-1004. https://doi.org/10.1080/03057925.2013.822244

Rind, I. A. (2015). Gender identities and female students' learning experiences in studying English as Second Language at a Pakistani University. Cogent Education, 2, 1115574. https://doi.org/10.1080/233118 6X.2015.1115574

Rind, I. A. (2016a). Conceptualizing students' learning experiences in English as second language in higher education from structure and agency. Cogent Social Sciences, 2(1), 1191978.

Rind, I. A. (2016b). How newly appointed ESL teachers' beliefs are translated into their pedagogic strategies. Journal of Research \& Method in Education, 6(1), 2320-7388. https://doi.org/10.9790/7388-0613124132

Rind, I. A., \& Alhawsawi, S. (2013). The effects of students' previous learning on graph-comprehension in the English as second language (ESL) textbooks in a Pakistani university. EducationalFutures, 5(2), 44-58. https:// educationstudies.org.uk/?p=630

Rind, I. A., \& Kadiwal, L. (2016). Analysing institutional influences on teaching-learning practices of English as second language programme in a Pakistani university. Cogent Education, 3(1), 1160606. https://doi.org/10.1 080/2331186X.2016.1160606

Rind, I. A., \& Ning, B. (2020). Evaluating scientific thinking among Shanghai's students of high and low performing schools. The Journal of Educational Research, 113, 364-373. https://doi.org/10.1080/00220671.2 020.1832430

Rind, I. A., Shahriar, A., \& Fatima, S. (2016). Rural-ethnic identities \& students'learning experiences in english as second language programme in a public sector university of Pakistan. The Sindh University Journal of Education-SUJE, 45(1), 1-20.

Roebuck, R. (2000). Subjects speak out: How learners position themselves in a Psycholinguistic task. In J.P. Lantolf (Ed.), Sociocultural theory and second language learning (pp. 79-85). Oxford University Press.

Scott, D. (1999). Values and Educational Research. Institute of Education.

Scott, David, \& Usher, R. (1996). Understanding educational research. Psychology Press.

Vygotsky, L. S. (1980). Mind in society: The development of higher psychological processes. Harvard University Press. 